\title{
Cytotoxic Selectivity of Ganoderma lucidum in Colon Cancer through \\ Cyclooxygenase 2 (COX-2) as Its Molecular Target
}

\author{
Agustina Setiawati * \\ Department Pharmaceutical Biology, Faculty of Pharmacy, Sanata Dharma University, Yogyakarta, Indonesia
}

\begin{abstract}
Many studies were designed explore chemopreventive activity of natural products on colon cancer especially addressing COX-2 as molecular target. Another promising source of natural product that potentially exhibit anticancer activity on colon cancer is Ganoderma lucidum. This study assessed selectivity of cytotoxic effect of G. lucidum extract on WiDr to Vero cells and investigated molecular mechanism on COX-2. G. lucidum extract was prepared by reflux extraction method; in vitro anticancer was assayed by MTT method on WiDr and Vero cell line. This study applied apoptosis induction assay to observe cell death mechanism using double staining method; further COX-2 expression was stained by immunocytochemistry method. G. lucidum extract has cytotoxic effect on WiDr cells with IC50 $135 \mu \mathrm{g} / \mathrm{mL}$. However, the cytotoxic effect had low selectivity towards Vero cells with Selectivity Index (SI) 3.66. The extract induced apoptosis and suppressed COX-2 expression in WiDr cells. G. lucidum extract was potential to be developed as anticancer agent towards colon cancer.
\end{abstract}

Keywords: Ganoderma lucidum, selectivity, colon cancer, $C O X-2$

\section{INTRODUCTION}

Colon cancer has high mortality case in developing countries [1] and it was ranked as the third most frequently diagnosed cancer in both of male and female in all of the countries $[1,2,3]$, as well as in the South East Asian Nations (ASEAN) countries [2, 3]. Since its incidence rapidly increases $[4,5]$, many studies are employed to prevent and cure colon cancer. There are many possible clinical treatments of colon cancer; such as surgery, chemotherapy, radiotherapy, and adjuvant chemotherapy $[5,6]$. However, painful, nausea, vomiting, skin changes, diarrhea, hair loss, bleeding and fatigue are severe side effects of the treatment [7]. The side effects arise because of non-selective and specific target of the treatments. Therefore, more studies set to discover specific and selective colon cancer treatment $[8,9,10]$ to kill colon cancer cells without endangering normal cells.

Colon cancer cells excessively produce cyclooxygenase $2(\mathrm{COX}-2)$ in both of carcinoma and adenoma $[11,12,13]$. COX-2, an enzyme that is responsible for

*Corresponding author:

Agustina Setiawati

Department of Pharmaceutical Biology, Faculty of Pharmacy, Sanata Dharma University

Campus III, Maguwoharjo, Depok, Yogyakarta, Indonesia 55284

E-mail: nina@usd.ac.id converting arachidonic acid to prostaglandins (PGs) [14], plays an important role in inflammation, cell proliferation and apoptosis regulation of colon cancer [15]. One of COX-2 product, prostaglandin E2 (PGE2), promotes angiogenesis and stimulates colon cancer growth by preventing apoptosis $[16,17]$. Thus, the inhibition activity of COX-2 is an alternative to suppress colon cancer. Previous studies concluded that COX-2 inhibitors successfully prevented colon cancer growth and polyp formation $[17,18,19,20,21,22]$. Therefore, COX-2 is an important molecular target for anticancer chemopreventive screenings on colon cancer.

Chemopreventive agents are compounds that are able to reverse cancer initiated cells to be normal cells. Chemopreventive agent is a strategy to specifically and selectively eliminate cancer. It should be able to block carcinogenesis process in promotion and progression stages [23]. Many studies investigated chemopreventive activity of natural products on colon cancer [24, 25, 26, 27], especially addressing COX-2 as molecular target

\section{How to cite:}

Setiawati A (2017) Cytotoxic Selectivity of Ganoderma lucidum in Colon Cancer through Cyclooxygenase 2 (COX-2) as Its Molecular Target. J. Trop. Life. Science 7 (2): 177 - 183. 
$[12,27]$. Among them, there was curcumin, a yellow pigment isolated from turmeric that successfully inhibited COX-2 on WiDr, a model of COX-2 overexpressing cancer cells [24].

Another promising source of natural product that potentially exhibit anticancer activity on colon cancer is Ganoderma lucidum. G. lucidum is well known as traditional medicine use against cancer, viral and bacterial infection, diabetes, and liver injury. Among its activities, its anticancer properties have been the most interesting studies [28]. It revealed cytotoxic activity of suppressed inflammatory breast cancer $[28,29,30]$, ovarian cancer [31], gastric cancer [32] and liver cancer [33]. A large number of chemical compounds can be extracted from the body or spores. There are two major compounds that had anticancer activity in G. lucidum; polysaccharides and triterpenoids. Polysaccharides of $G$. $l u-$ cidum boosted cytotoxic immune cells so that it could induce apoptosis in cancer cells [34]. Other compounds in G. lucidum, terpenoid compounds revealed cytotoxic, antioxidant as well as antiinflammation activity on cancer cells through immune modulation [35-37]. Terpenoids isolated from $G$. lucidum activated NF-KB, a transcription factor that regulated COX-2 expression in cancer cells $[38,39]$. They excessively induced cell cycle arrest on G1 phase through immune boosting in colon cancer xenograft model [40]. Another study underlined that ethanolic extract of G. lucidum decreased COX-2 expression and increased nitric oxide synthesis in colon HT-29 cells [41]. Therefore, G. lucidum is a potential to be developed as chemopreventive agent on colon cancer with COX-2 as the target. Moreover, the molecular pathway involving COX-2 of G. lucidum will give a positive contribution to assess its specificity on colon cancer cells.

However, the selectivity of G. lucidum as chemopreventive agent is still remaining questioned. Besides the specificity, the selectivity of a chemopreventive agent is also important to investigate. Valadan et al [42] reported G. lucidum had cytotoxicity on Vero cells, a model of normal cells. Selectivity Index (SI) (IC50 Vero cells/IC50 cancer cells) indicated cytotoxicity selectivity of a compound or extract to kill normal cells versus in cancer cells $[42,43]$. Furthermore, investigating selectivity of cytotoxic effect of G. lucidum is an interesting to be further studied.

This study assessed cytotoxic effect of ethanolic extract of G. lucidum on WiDr as well as Vero cells and determined SI of the extract. Furthermore, the molecular mechanism of death cells was investigated with apop- tosis assay using double staining method and immunocytochemistry of COX-2.

\section{MATERIALS AND METHODS \\ Plant material}

G. lucidum was harvested in June, 2015 from Pandowoharjo, Sleman, Yogyakarta, Indonesia.

\section{Chemicals}

Celecoxib was purchased from Sigma-Aldrich with $\geq 98 \%$ purity. Vero and WiDr cells were cultivated in Fetal Bovine Serum (FBS) 10\% (v/v) (Gibco) and 1\% $(\mathrm{v} / \mathrm{v})$ streptomycin and penicillin (Gibco) in Roswell Park Memorial Institute Medium (RPMI) (Gibco). To dissolve the extract and celecoxib, this study used dimethyl sulfoxide (DMSO) (Merck).

Immunocytochemistry used COX-2 primary antibody from Thermo Scientific Lab Vision and secondary antibody was diluted from Starr Trek HRP universal detection system No.901-STUHRP700-090314. All plates and micro plate in this study were Iwaki ${ }^{\circledR}$, moreover blue, yellow and white tips were supplied by Axygen ${ }^{\circledR}$.

\section{Extraction}

G. lucidum was dried using oven and homogenously powdered. $10 \mathrm{~g}$ of its powder was extracted in $90 \%$ ethanol using reflux method for 2 hours. Liquid extract was evaporated under $80^{\circ} \mathrm{C}$ until reached constant weight.

\section{Cytotoxic assay}

Cytotoxic assay towards Vero cells as well as WiDr cells were designed based on our previous studies [4546]. Cells were seeded in a culture tissue flask until $80 \%$ confluent, then $5 \times 10^{3}$ cells were planted into a 96-well micro plate. The cells cultivated in an incubator under $37^{\circ} \mathrm{C}$ and $5 \% \mathrm{CO} 2$. The medium was discarded and the cells were gently washed two times using PBS. The initial solution of extract was provided by dissolving them into DMSO and diluted them in DMEM into several concentrations. Each of extract concentration was added $100 \mu \mathrm{L}$ into each well of the 96-wells micro plate and tested in three times in a set. Moreover, the cells were incubated in the same condition as the previous step. The medium was then discarded and the medium contained $10 \%$ MTT was spilled into each well. The reaction between succinate hydrogenase of cell mitochondrion and MTT to form formazan took 3 until 4 hours. After 4 hours incubation, $100 \mu \mathrm{L}$ of $10 \%$ SDS solution was poured to each well to dissolve formazan crystals. 
The plate was wrapped in dark paper to avoid light exposure and incubated 12-24 hours, then formazan complex was measured in $595 \mathrm{~nm}$ visible wavelength using ELISA reader.

\section{Apoptosis induction assay}

Apoptosis induction assay was conducted only in WiDr cells. The cells were cultured $5 \times 10^{4}$ on coverslips in 24-well plate. WiDr cells were adapted in $37^{\circ} \mathrm{C}$ and $5 \%$ CO2 for 24 hours. Then, the medium was discarded and twice soaked in PBS. The extract and celecoxib at IC50 concentration $(135 \mu \mathrm{g} / \mathrm{mL}$ and $68 \mu \mathrm{M})$ were poured into the plate then it was incubated in the same as previous condition. IC50 concentration of celecoxib was calculated from our previous study [47]. The medium was removed from WiDr cells and they were twice soaked in PBS. The coverslips were taken from the plate and moved to glass objects, and then acridine orangeethidium bromide (AE) was added into the coverslips. The glass objects were immediately investigated under fluorescence microscope.

\section{Immucytochemistry assay}

WiDr cells were spread in 6-well plate and placed in incubator with $5 \% \mathrm{CO} 2$ and $37^{\circ} \mathrm{C}$ for 24 hours. The extract at $135 \mu \mathrm{g} / \mathrm{mL}$ and celecoxib at $68 \mu \mathrm{M}$ were treated on cells and incubated for 24 hours. At the end of the incubation time, cells were collected and washed in PBS three times. The cells were suspended in medium, placed and fixed in object glass for 5 minutes. Hydrogen peroxidase was added into the object glass and placed in room temperature for 10-15 minutes. Then, it was gently washed by PBS twice and monoclonal antibody of COX-2 was dropped into the object glass at least for an hour. The object glass was washed in PBS and secondary antibody was dropped into the glass. It was incubated in room temperature for ten minutes, later it was washed four times in PBS. The solution of 3, 3'diaminobenzidine $(\mathrm{DAB})$ as chromogen was poured into the cells and incubated for 3- 8 minutes. Finally, the object glass was washed by aquadest and hematoxylin solution was added. It was incubated for 3-4 minutes and dried. The expression of COX-2 was observed under inverted microscope.

\section{Data analysis} equation:

Cell viability was calculated from MTT data using

$$
\frac{\text { Sample treatment absorbance }- \text { Medium absorbance }}{\text { Untreated cells absorbance }- \text { Medium absorbance }} \times 100 \%
$$

Cell viability data was analyzed using linier regressions to calculate IC50 of extract and celecoxib. This SI was calculated by dividing IC50 towards Vero cells/IC50 towards Vero cells [19]. The number of apoptosis, necrosis and living cells was semi-quantitative analyzed by blind observed by blind counting cell distribution in three areas of object glass.

\section{RESULTS AND DISCUSSION}

G. lucidum extract demonstrated dose-depend cytotoxic activity both in WiDr cells (Figure 1a) and Vero cells (Figure $1 \mathrm{~b}$ ). It had IC50 $135 \mu \mathrm{g} / \mathrm{mL}$ towards WiDr cells and $494 \mu \mathrm{g} / \mathrm{mL}$ towards Vero cells. Cell morphology observation revealed G. lucidum extract IC50 concentration on slightly effected cell population otherwise celecoxib dramatically effected cell population than the extract (Figure 2). By comparing IC50 in Vero cells to IC50 in WiDr cells, the SI was determined 3.66 respectively.

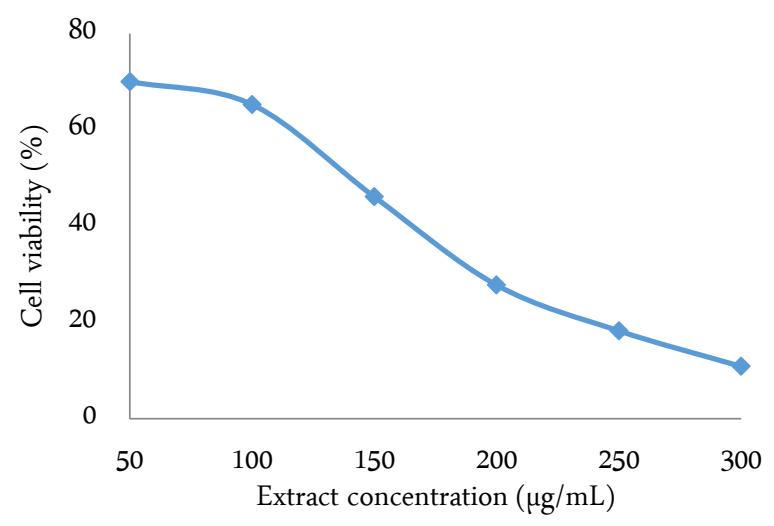

(a)

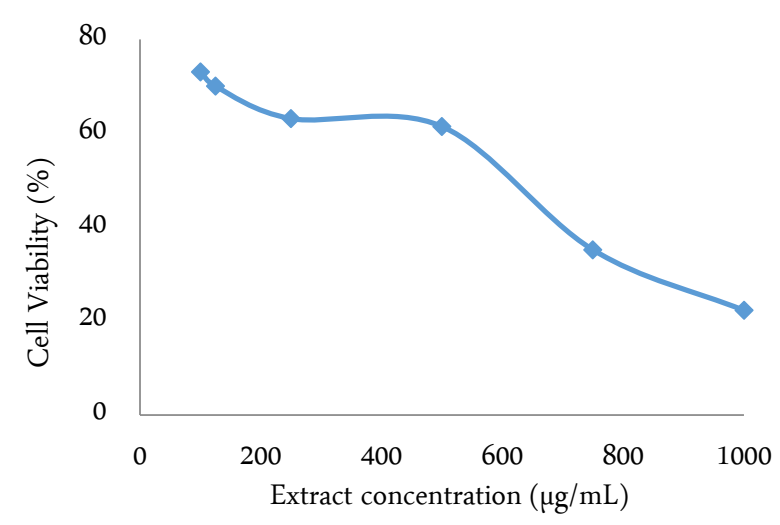

(b)

Figure 1. The effect of G. lucidum extract on WiDr cells (a) and Vero cells (b) 
Tabel 1. Cell distribution in apoptosis assay

\begin{tabular}{cccc}
\hline Treatment & Apoptosis $(\%) \pm$ SD & Necrosis $(\%) \pm$ SD & Living $(\%) \pm S D$ \\
\hline G. lucidum extract & $46.4 \pm 0.56$ & $5.21 \pm 1.12$ & $48.40 \pm 5.95$ \\
Celecoxib & $81.80 \pm 0.88$ & $3.48 \pm 1.43$ & $14.68 \pm 0.65$ \\
Untreated cells & $1.42 \pm 0.65$ & $0.72 \pm 0.04$ & $97.86 \pm 0.61$ \\
\hline
\end{tabular}

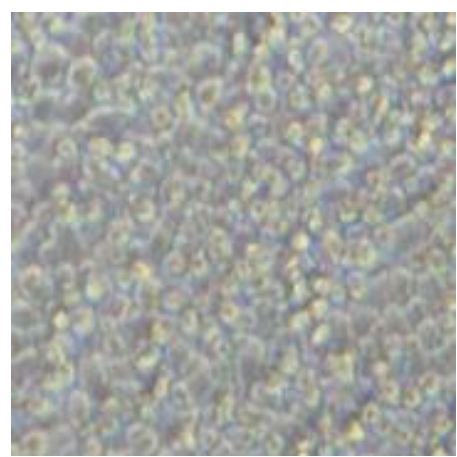

(a)

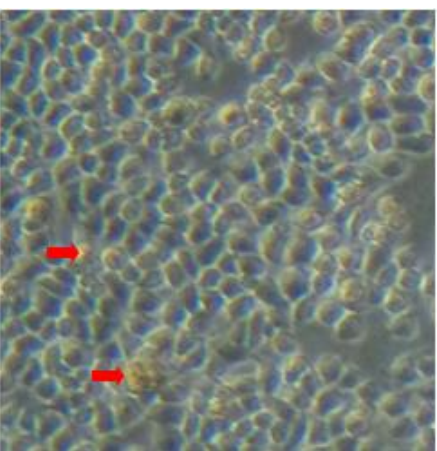

(b)

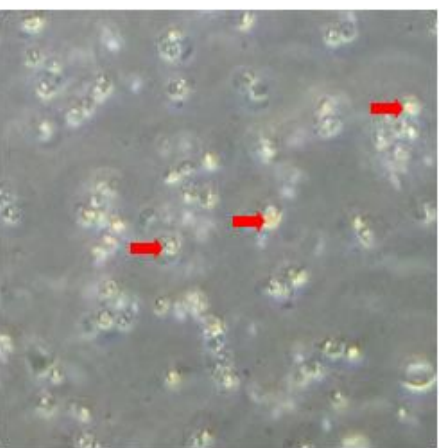

(c)

Figure 2. Morphology observation of WiDr cells under light microscope using $400 \times$ magnification in untreated cells (a), cells treated by $135 \mu \mathrm{g} / \mathrm{mL}$ extract (b), and cells treated by $68 \mu \mathrm{M}$ celecoxib (c). Living and dead cells are indicated by white arrow and red arrow.

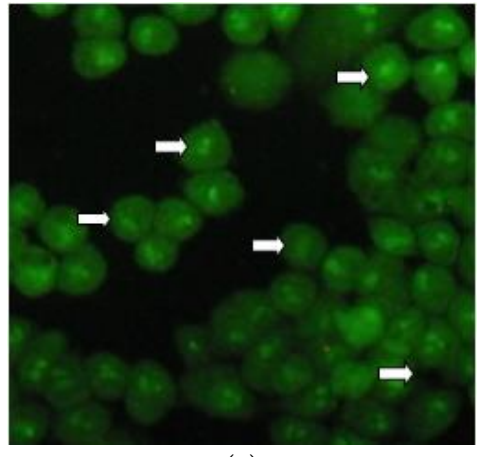

(a)

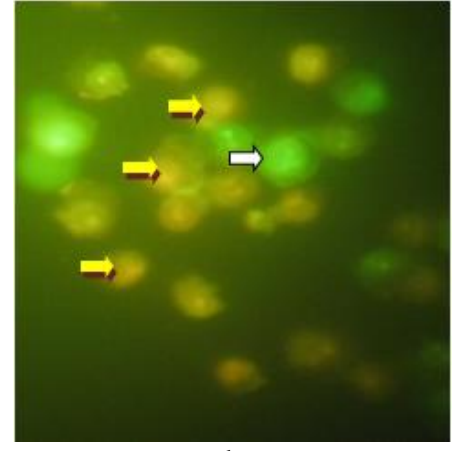

(b)

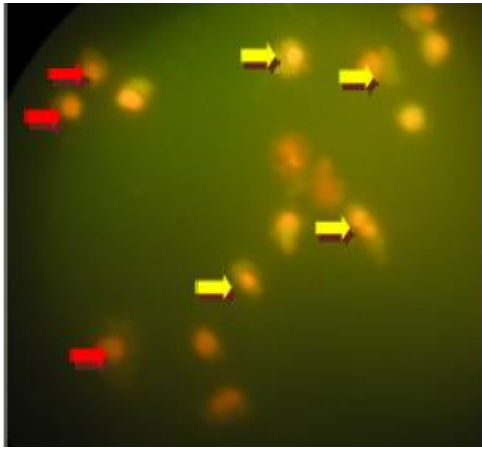

(c)

Figure 3. Apoptotic observation in WiDr cells using double staining method under flourenscence microscopy using $400 \times$ magnification in untreated cells (a), cells treated by $135 \mu \mathrm{g} / \mathrm{mL}$ extract (b), and cells treated by $68 \mu \mathrm{M}$ celecoxib (c). Living, dead, and apoptotic cells are indicated by white arrow, red arrow, and yellow arrow.

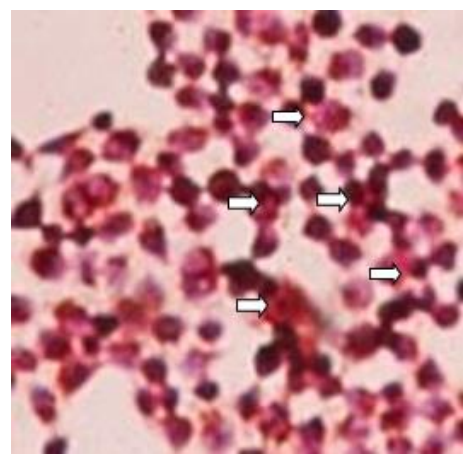

(a)

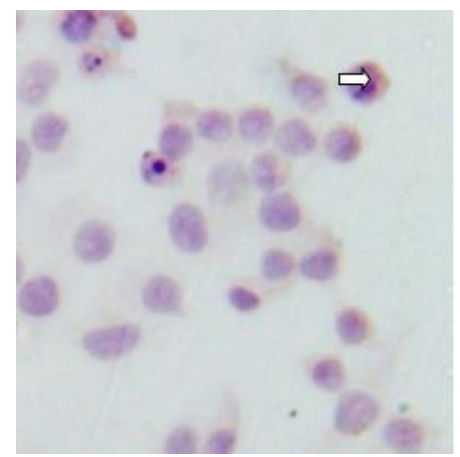

(b)

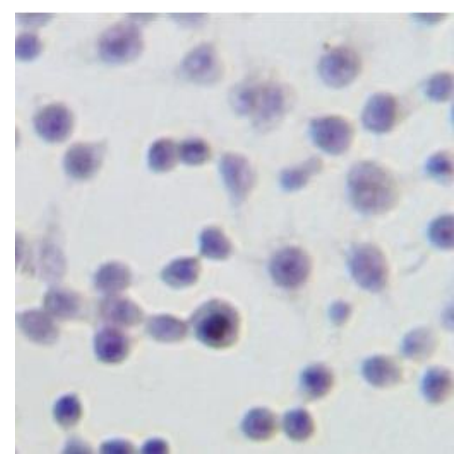

(c)

Figure 4. COX-2 expression in WiDr cells under light microscope using $400 \times$ magnification in untreated cells (a), cells treated by 135 $\mu \mathrm{g} / \mathrm{mL}$ extract (b), and cells treated by $68 \mu \mathrm{M}$ celecoxib (c). Brown colour shows COX-2 expression in cells. 
Furthermore, this study investigated apoptosis induction in WiDr cells using double staining method. The nuclei showed condensed yellow-green fluorescence by acridine orange in early stage of apoptosis. On the other hand, nuclei of cells showed condensed orange fluorescence by ethidium bromide in late apoptosis stage [47]. Apoptosis cells were showed in orange colour with condensed nuclei while necrosis cells was stained in orange colour with uncondensed nuclei (Figure 3). G. Iucidum extract as well as celecoxib induced apoptosis in WiDr cell (Table 1). It confirmed from our previous research that celecoxib strong induced apoptosis in $\mathrm{WiDr}$ cells [47]. Molecular mechanism of extract in WiDr cells was further investigated through COX-2 expression analysis. COX-2 suppressing cells were stained in brown color while non-suppressing cells were stained in purple color. Immunocytochemistry staining revealed extract suppressed COX-2 expression. This suppression of the extract was lower than celecoxib (Figure 4).

Overall, this study evaluated cytotoxic activity of G. lucidum extract on $\mathrm{WiDr}$ colon cancer cells and its selectivity on normal cells. This study was designed to discover new therapeutic agent of colon cancer that has less side effects to cancer patient. This study used Vero cells, as model of normal mammalian cell line that derived from the kidney of the African green monkey (Cercopithecus aethiops). This cell line was recommended for screening chemical toxicity in vitro $[48,49]$.

Selectivity Index (SI) is parameter that indicates selectivity of a compound or an extract. Based on Moustafa et al. (2014) [43], the SI value of G. lucidum extract (SI value $<10$ ) was consider as unselective extract towards normal cells. However, other studies mentioned that SI value $<2$ indicating high selectivity $[50,51] . G$. lucidum extract induced apoptosis in WiDr cells.

Instead of its selectivity and apotosis induction, molecular mechanism of G. lucidum extract on WiDr cells must be further investigated. This study focused on COX-2 protein that produced PGE2 that increased cell proliferation and escaped from apoptosis [16, 17]. Therefore, COX-2 is important target to screen chemopreventive agent on colon cancer. The result of this study showed that G. lucidum extract suppressed COX2 expression in WiDr. The suppression effect was lower than celecoxib, a selective COX-2 inhibitor, as positive control. Celecoxib is one of prospective drug against colon cancer [52] and our previous research showed it suppressed COX-2 expression in WiDr cells [47]. The suppression effect of the extract may be activated by terpenoids in G. lucidum to NF-KB, a transcription factor that regulated COX-2 expression in cancer cells [38, 39].

G. lucidum extract offers a new promising for selective chemopreventive agent on colon cancer. Our data revealed it inhibited COX-2 expression, even though detail molecular mechanism of these benefit remain to be established in the future study

\section{CONCLUSION}

G. lucidum extract has selective cytotoxic effect towards WiDr cells than Vero cells. It molecular mechanism in WiDr cells involved COX-2 suppression.

\section{ACKNOWLEDGMENT}

The author is grateful to Skolastika who help in technical work during the G. lucidum extraction.

\section{REFERENCES}

1. Torre LA, Bray F, Siegel RL et al. (2015) Global Cancer Statistics. CA: Cancer Journal for Clinicians 65: 87- 107. doi: 10.3322/caac.20107.

2. World Health Organization (2013) Latest world cancer statistics Global cancer burden rises to 14.1 million new cases in 2012: Marked increase in breast cancers must be addressed. https://www.iarc.fr/. Accessed: March 2015.

3. Kimman M, Norman R, Jan S et al. (2012) The Burden of cancer in member countries of the association of Southeast Asian Nations (ASEAN). Asian Pacific Journal of Cancer Prevention 13 (2): 411-420.

4. Jemal A, Center MM, DeSantis C, Ward EM (2010) Global pattern of cancer incidence and mortality rates and trends. Cancer Epidemiology, Biomarkers and Prevention 9 (8): 1893- 1907. doi: 10.1158/1055-9965.EPI-10-0437.

5. Labianca R, Nordinger B, Beretta GD et al. (2010) Primary colon cancer: ESMO clinical practical guidelines for diagnosis, adjuvant treatment and follow-up. Annals of Oncology 21 (Supplement_5): v70-v77. doi: 10.1093/annonc/mdq168.

6. Association of Coloproctology of Great Britain and Ireland (2007) Guideline for the Management of Colorectal Cancer. London. 3rd Edition. http://www.uhb.nhs.uk/. Accessed: April 2015.

7. American Cancer Society. Colon Cancer: Facts and Figure 2014-2016. https://www.cancer.org/ Accessed: April 2015.

8. Jiang Y, Zhang C, Chen K et al. (2014) The clinical significance of DC-SIGN and DC-SIGNR, which are Novel markers expressed in human colon cancer. PLoS ONE. 9 (12): e114748. doi: 10.1371/journal.pone.0114748.

9. Wang XW, Zhang YJ (2014) Targeting mTOR network in colorectal cancer therapy. World Journal of Gastroenterology 20 (15): 4178- 4188. doi: 10.3748/wjg.v20.i15.4178. 
10. Mishra J, Dromund J, Quazi SH et al. (2013) Prospective of colon cancer treatments and scope for combinatorial approach to enhanced cancer cell apoptosis. Critical Reviews in Oncology/Hematology 86 (3): 232-250. doi: 10.1016/j.critrevonc.2012.09.014.

11. Dixon DA, Blanco FF, Bruno A, Patrignani P (2013) Mechanistic Aspects of COX-2 Expression in Colorectal Neoplasia. In: Chan AT, Detering E (eds) Prospect. Chemoprevention Color. Neoplasia. Berlin, Springer, pp 7-37. doi: 10.1007/978-3-642-30331-9_2.

12. Qi J, Dong Z, Liu J, Zhang JT (2014) EIF3i promotes colon oncogenesis by regulating COX-2 protein synthesis and $\beta$ catenin activation. Oncogene 33 (32): 4156-4163. doi: 10.1038/onc.2013.397.

13. Roelofs HMJ, Te Morsche RHM, van Heumen BWH et al. (2014) Over-expression of COX-2 mRNA in colorectal cancer. BMC Gastroenterology 14 (1): 1- 6. doi: 10.1186/1471230X-14-1.

14. Park J, Conteas CN (2010) Anti-carcinogenic properties of curcumin on colorectal cancer. World Journal of Gastrointestinal Oncology 2 (4): 169-176. doi: 10.4251/wjgo.v2.i4. 169.

15. Sobolewski C, Cerella C, Dicato M et al. (2010) The Role of Cyclooxygenase-2 in cell proliferation and cell death in human malignancies. International Journal of Cell Biology 2010 (2010): 1-21. doi: 10.1155/2010/215158.

16. Nakanishi M, Rosenberg DW (2013) Multifaceted roles of PGE2 in inflammation and cancer. Seminars in Immunopathology 35 (2): 123-137. doi: 10.1007/s00281-012-03428.

17. Li HJ, Reinhardt F, Herschman HR, Weinberg RA (2012) Cancer-stimulated mesenchymal stem cells create a carcinoma stem-cell niche via Prostaglandin E2 signaling. Cancer Discovery 2 (9): 840- 855. doi: 10.1158/2159-8290.CD12-0101.

18. Ghosh N, Chaki R, Mandal V et al. (2011) COX-2 as a target for cancer chemotherapy. Pharmacological Reports. 62: 233-244.

19. Rahman M, Selvarajan K, Hasan MR et al. (2012) Inhibition of COX-2 in colon cancer modulate tumor growth and MDR-1 expression to enhance tumor regression in therapyrefractory cancers in vivo. Neoplasia 14 (7): 624-633.

20. Kodela R, Chattopadhyay M, Goswami S et al. (2013) Positional isomers of Aspirin are equally potent in inhibiting colon cancer cell growth: Differences in mode of cyclooxygenase inhibition. The Journal of Pharmacology and Experimental Therapeutics 345 (1): 85-94. doi: 10.1124/jpet.112. 201970.

21. Makar KW, Poole EM, Resler AJ et al. (2013) COX-1
(PTGS1) and COX-2 (PTGS2) polymorphisms, NSAID interactions, and risk of colon and rectal cancer in two independent populations. Cancer Causes and Control 24 (12): 2059-2075. doi: 0.1007/s10552-013-0282-1.

22. Kuno T, Tsukamoto T, Hara A, Tanaka T (2012) Cancer chemoprevention through the induction of apoptosis by natural compounds. Journal of Biophysical Chemistry 3 (2): 156- 173. doi: 10.4236/jbpc.2012.32018.

23. Rosas C, Sinning M, Ferreira A et al. (2014) Celecoxib decreases growth and angiogenesis and promotes apoptosis in a tumor cell line resistant to chemotherapy. Biological Research 4 (1): 27. doi: 10.1186/0717-6287-47-2.

24. Jaganathan SK, Vellayappan MV, Narasimhan G, Supriyanto E (2014) Role of pomegranate and citrus fruit juices in colon cancer prevention. World Journal of Gastroenterology 20 (16): 4618-4625. doi: 10.3748/wjg.v20.i16.46 18.

25. Amado NG, Predes D, Moreno MM et al. (2014) Flavonoids and $\mathrm{Wnt} / \beta$-Catenin signaling: Potential role in colorectal cancer therapies. International Journal of Molecular Science 15: 12094- 12106. doi: 10.3390/ijms150712094.

26. Nassar ZD, Aisha AF, Idris N et al. (2012) Koetjapic acid, a natural triterpenenoids, induces apoptosis in colon cancer cells. Oncology Reports 27: 727- 733. doi: 10.3892/or.2011. 1569.

27. Patel VB, Misra S, Patel BB, Majumdar APN (2010) Colorectal cancer: Chemopreventive role of curcumin and resveratrol. Nutrition and Cancer 62 (7): 958-967. doi: 10.1080/01635581.2010.510259.

28. Galor SW, Yuen J, Buswell JA, Benzie IFF (2011) Ganoderma lucidum (Lingzhi or Reishi), a medicinal mushroom in herbal medicine: Biomolecular and clinical aspects 2nd edition. Florida, CRC Press/Taylor and Francis.

29. Arroyo IJ, Acevedo RR, Perez AA et al. (2013) Anti-tumor effects of Ganoderma ludicum (Reishi) in inflammatory breast cancer in in vivo and in vitro models. PLoS One 8 (2): e57431. doi: 10.1371/journal.pone.0057431.

30. Zhao H, Zhang Q, Zhao L et al. (2012) Spore powder of Ganoderma lucidum improves cancer-related fatigue in breast cancer patients undergoing endocrine therapy: a pilot clinical trial. Evidence-Based Complementary and Alternative Medicine. doi: 10.1155/2012/809614

31. Dai L, Sun W (2014) Ganoderma lucidum inhibits proliferation of human ovarian cancer cells by suppressing VEGF expression and up-regulating the expression of connexin 43. BMC Complementary and Alternative Medicine 14: 434. 14:434. doi: 10.1186/1472-6882-14-434.

32. Jang KJ, Han MH, Lee BH et al. (2010) Induction of apop- 
tosis by ethanol extracts of Ganoderma lucidum in human gastric carcinoma cells. Journal of Acupuncture and Meridian Studies 3 (1): 24-31. doi: 10.1016/S2005-2901(10)600040 .

33. Cao LZ, Lin ZB (2003) Regulatory effect of Ganoderma lucidum polysaccharides on cytotoxic T-lymphocytes induced by dendritic cells in vitro. Acta Pharmacologica Sinica 24 (4): 312-326.

34. Weng CJ, Chau CF, Yen GC et al. (2009) Inhibitory effects of Ganoderma lucidum on tumorigenesis and metastasis of human hepatoma cells in cells and animal models. Journal of Agricultural and Food Chemistry 57 (11): 5049-5057. doi: 10.1021/jf900828k.

35. Kao CHJ, Jesuthasan AC, Bishop KS et al. (2013) Anticancer activities of Ganoderma lucidum: active ingredients and pathways. Functional Food in Health and Disease 3 (2): 48-65.

36. Calvino E, Pajuelo L, Casas OE et al. (2011) Cytotoxic Action of Ganoderma lucidum on Interleukin-3 Dependent Lymphoma DA-1 cells: Involvement of apoptosis protein. Phytotherapy Research 25 (1): 25-32. doi: 10.1002/ptr.3202.

37. Wu GS, Guo JJ, Bao JL et al. (2013) Anti-cancer properties of triterpenoids isolated from Ganoderma lucidum - a review. Expert Opinion on Investigational Drugs 22 (8): 98192. doi: 10.1517/13543784.2013.805202.

38. Montemayor MM, Acevedo RR, Franqui EO et al. (2011) Ganoderma lucidum (Reishi) inhibits cancer cell growth and expression of key molecules in inflammatory breast cancer. Nutrition and Cancer 63 (7): 1085-1094. doi: 10.1080/01635581.2011.601845.

39. Jiang J, Slivova V, Harvey K et al. (2004) Ganoderma lucidum suppresses growth of breast cancer cells through the inhibition of Akt/NF-KB signaling. Nutrition and Cancer 49 (2): 209- 216. doi: 10.1207/s15327914nc4902_13.

40. Thyagarajan A, Jedinak A, Nguyen H et al. (2010) Triterpenes from Ganoderma lucidum induce autophagy in colon cancer through the inhibition of p38 mitogen-activated kinase (p38 MAPK). Nutrition and Cancer 62 (5): 630-640. doi: 10.1080/01635580903532390.

41. Hong KJ, Dunn DM, Shen CL, Pence BC (2004) Effects of Ganoderma lucidum on apoptotic and anti-inflammatory function in HT-29 human colonic carcinoma cells. Phytotherapy Research 18 (9): 768-770. doi: 10.1002/ptr.1495.

42. Valadan S, Ahmadi R, Sadri M, Mahdavi E (2014) Antiproliferative effects of Ganoderma lucidum in cell culture on Vero cells. In proceedings of International Conference on Chemical, Environment and Biological Sciences (CEBS - 2014): 17- 18 September 2014; Kuala Lumpur. Edited by Rahman A, Ahmadi R.

43. Moustafa SMA, Menshawi BM, Wassel GM et al. (2014) Screening of some plants in egypt for their cytotoxicity against four human cancer cell lines. International Journal of PharmTech Research 6 (3): 1074-1084.

44. Irungu BN, Adipo N, Orwa JA et al. (2015) Antiplasmodial and cytotoxic activities of the constituents of Turraea robusta and Turraea nilotica. Journal of Ethnopharmacology 174: 419-425. doi: 10.1016/j.jep.2015.08.039.

45. Setiawati A (2016) Celecoxib, A COX-2 selective inhibitor, induces cell cycle arrest at the G2 / M phase in hela cervical cancer cells. Asian Pacific Journal of Cancer Prevention 17 (4): 1655-1659.

46. Calderón-arancibia J, Espinosa-bustos C, Cañete-molina Á et al. (2015) Synthesis and pharmacophore modelling of 2,6,9-Trisubstituted Purine derivatives and their potential role as apoptosis-inducing agents in cancer cell lines. Molecules 20 (4): 6808-6826. doi: 10.3390/molecules20046808.

47. Setiawati A, Immanuel H, Utami MT (2016) The Inhibition of Typhonium flagelliforme Lodd. Blume leaf extract on COX-2 expression of WiDr colon cancer cells. Asian Pacific Journal of Tropical Biomedicine 6 (3): 251-255. doi: 10.1016/j.apjtb.2015.12.012.

48. U.S. Department of Health and Human Services - Food and Drug Administration (2016) Biological evaluation of medical devices - Part 5: Tests for cytotoxicity: in vitro methods.3: 42. https://www.fda.gov/. Accessed: April 2017.

49. Menezes C, Valerio E, Dias E (2013) The Kidney Vero-E6 Cell Line: A Suitable Model to Study the Toxicity of Microcystins. New Insights into Toxic Drug Test. doi: 10.5772/54463

50. Awang N, Aziz ZA, Kamaludin NF, Chan KM (2014) Cytotoxicity and mode of cell death induced by Triphenyltin (IV) compounds in vitro. OnLine Journal of Biological Sciences 14 (2): 84-93. doi: 10.3844/ojbsci.2014.84.93.

51. Machana S, Weerapreeyakul N, Barusrux S et al. (2011) Cytotoxic and apoptotic effects of six herbal plants against the human hepatocarcinoma (HepG2) cell line. Chinese Medicine 6 (1): 39. doi: 10.1186/1749-8546-6-39.

52. Dixon DA, Blanco FF, Bruno A, Patrignani P (2013) Mechanistic aspects of COX-2 expression in colorectal neoplasia. Recent Results in Cancer Research 191: 7-37. doi: 10.1007/978-3-642-30331-9_2. 